\title{
Influence of the Housing System and the Season on Some Parameters Indicative of the Welfare of Dairy Cows in Eastern Algeria
}

\author{
Imene DJAALAB ${ }^{1}{ }^{*}$, Hadria MANSOUR-DJAALAB ${ }^{1}$, Foulla RIACHI ${ }^{1}$, Abdel Fattah BEGHRICHE ${ }^{2}$, \\ Samia HAFFAF ${ }^{3}$, Assia ALLAOUI ${ }^{2}$, Loutfi GHORIBI ${ }^{1}$ \\ ${ }^{1}$ Laboratory Pharmacology Toxicology, Institute of Veterinary Sciences El-Khroub, Constantine University of the \\ Brothers Mentouri, 025100, Algeria \\ 2 Institute of Veterinary Sciences El-Khroub, Constantine University of the Brothers Mentouri, 025100, Algeria \\ ${ }^{3}$ Department of Agronomic Sciences, Faculty of Sciences, University of M'Sila, 028000, Algeria. \\ * Corresponding author: I. Djaalab e-mail: imendjaalab@gmail.com
}

RESEARCH ARTICLE

\begin{abstract}
The purpose of this study is to evaluate the effect of housing systems (free vs. tie-stall) and season (winter vs. spring) on the welfare of dairy cows through indices of cleanliness, leg health (straightness, hocks and knees), lameness score, body condition and milk production. This is to test the hypothesis that dairy cows in spring and free-stalls have a better quality of well-being than those kept in tie stalls in winter. For that, 299 dairy cows of the Holstein and Montbeliard breeds were selected from dairy farms in 6 communes of the Constantine governorate in eastern Algeria. The results showed that tie-stalled farms in winter were characterized by a lack of hygiene $(\mathrm{P}<0.001)$, with a stall cleanliness score of 7.62 and a frequency of $32.60 \%$ of dirty to very dirty cows. In the spring, the incidence of severe lameness does not exceed $9 \%$ in farms with tie stalls and more than $41 \%$ in mild lameness in housing with free stalls $(\mathrm{P}<0.001)$. Cows in tie stalls show a deviation of legs of $17^{\circ}$ to $24^{\circ}$ $(57.97 \%)$. On the other hand, more than half of cows in free stalls show integumentary lesions (alopecia and swelling) of the carpal $(60.25 \%)$ and tarsal joints $(54.22 \%)(\mathrm{P}<0.001)$. The percentage of fairly lean cows (score $2-2.5$ ), housed in tie stalls, was significantly higher (18 to 44\%) with a significantly low milk production ( $\mathrm{P}$ $<0.001$ ). These results reflect a lack of comfort in tie-stall farms during winter which has an impact on dairy performance.
\end{abstract}

Keywords: Welfare; dairy cows; housing type; season; Algeria.

Received: 14 September 2020

Accepted: 08 April 2021

Published: 15 May 2021

DOI:

10.15835/buasvmcn-asb:2020.0020

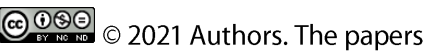
published in this journal are licensed under the Creative Commons Attribution-NonCommercialNoDerivatives 4.0 International License
}

\section{INTRODUCTION}

The science of animal welfare is seen as an important factor in improving production systems through the evaluation of methods for improving animal handling, housing and management conditions. This encourages developing countries to create and enforce explicit animal welfare standards by integrating animal welfare as a national and international policy, for trade and trade component (Fraser, 2014).

In Africa, livestock represents almost $30 \%$ of the gross domestic product of agriculture and nearly $10 \%$ of the national gross domestic product. It is estimated that about 300 million people depend on livestock for their incomes (AU-IBAR, 2010). As a result, livestock are considered an important asset in the African continent. However, in most of the North African countries such as Algeria, animal welfare is rarely the subject of specific legislative or regulatory provisions (Molomo and Mumba, 2014). On the other hand, animal welfare is considered critically important by the World Organisation for Animal Health 
(OIE), and its assessment is regarded as a tool being used by most researchers in African countries (Allane et al., 2011; Bouraoui et al., 2014; Benatallah et al., 2015; Kathambi et al., 2019; Darej et al., 2019).

Consequently, the assessment of animal welfare consists in the development of objective indicators which are both capable of providing information about the quality of life of an animal, and capable of providing scientifically reliable data that are immediately usable by professionals (De Vries et al., 2011). As animals are sentient beings who can experience both positive and negative emotions, the indicators must reflect not only their physical health but also their feelings about the conditions where they live (Wemelsfelder and Mullan, 2014).

It becomes clear that the different environmental factors and housing equipment can influence the animal's ability to survive (Popescu et al., 2014a). Thus, the number, design and location of feeders and waterers can influence livestock activities (food intake and water supply) but also their social behavior and the occurrence of physical injuries, thus affecting productivity, health and welfare of livestock (Rousing et al., 2000).

Unlike traditional confined housing systems, free systems ensure better udder health (De Pinho Manzi et al., 2012; M'Sadak et al., 2015), lower risk of ketosis and better fertility (Relić and Vuković, 2013; Bugueiro et al., 2020), expressing superior potential and performance for improved animal welfare (Vučemilo et al., 2012). In addition, dairy cows housed in free housing benefit from outdoor exercise, positively impacting their health and well-being Popescu et al., 2013; (Dohme-Meier et al., 2014; Shepley et al., 2019b). However, some studies point out that this type of free housing causes a higher risk of lameness (Cook, 2003; Sogstad et al., 2005).

The present study in this context highlights the impact of the type of housing (free and tied stall) in two different seasons (winter and spring). The aim is to identify the strengths and weaknesses of these agricultural housing systems and their repercussions on the health and well-being of dairy cows through the use of indicators.

\section{MATERIALS AND METHODS}

\section{Ethical approval}

The ethical considerations in accordance to the Institute Animal Ethics Committee related to animal handling were observed to ensure no pain to the animals during the current study.

\section{Study area and survey locations}

The department of Constantine is a region of plains and mountainous terrain which covers an area of 222.910 hectares (DSA, 2018). It is located in the north-east of Algeria, on the Tellian Atlas Mountains (Figure 1). The predominance of mountains and the presence of high plains are the main landforms of this region. The forest area represents $12.6 \%$ of the total area of the governorate (DSA, 2018). The climate is classified as a Mediterranean type with distinct seasons, that is, a cold and rainy winter and a hot and dry summer. Rainfall ranges from 400 to $600 \mathrm{~mm}$ per year. There is a marked bioclimatic gradient in this region where the sub-humid climate is warm with minimum temperature variants of $-6^{\circ} \mathrm{C}$ in winter to a maximum of $47^{\circ} \mathrm{C}$ in summer. The prevailing winds are those of the North-Northwest with winter rain and snow.

In 2018, the national cattle population was estimated at 1.9 million head, including more than $52 \%$ of dairy cows and nearly 55177 head of cattle at the Constantine governorate (MADR, 2018).

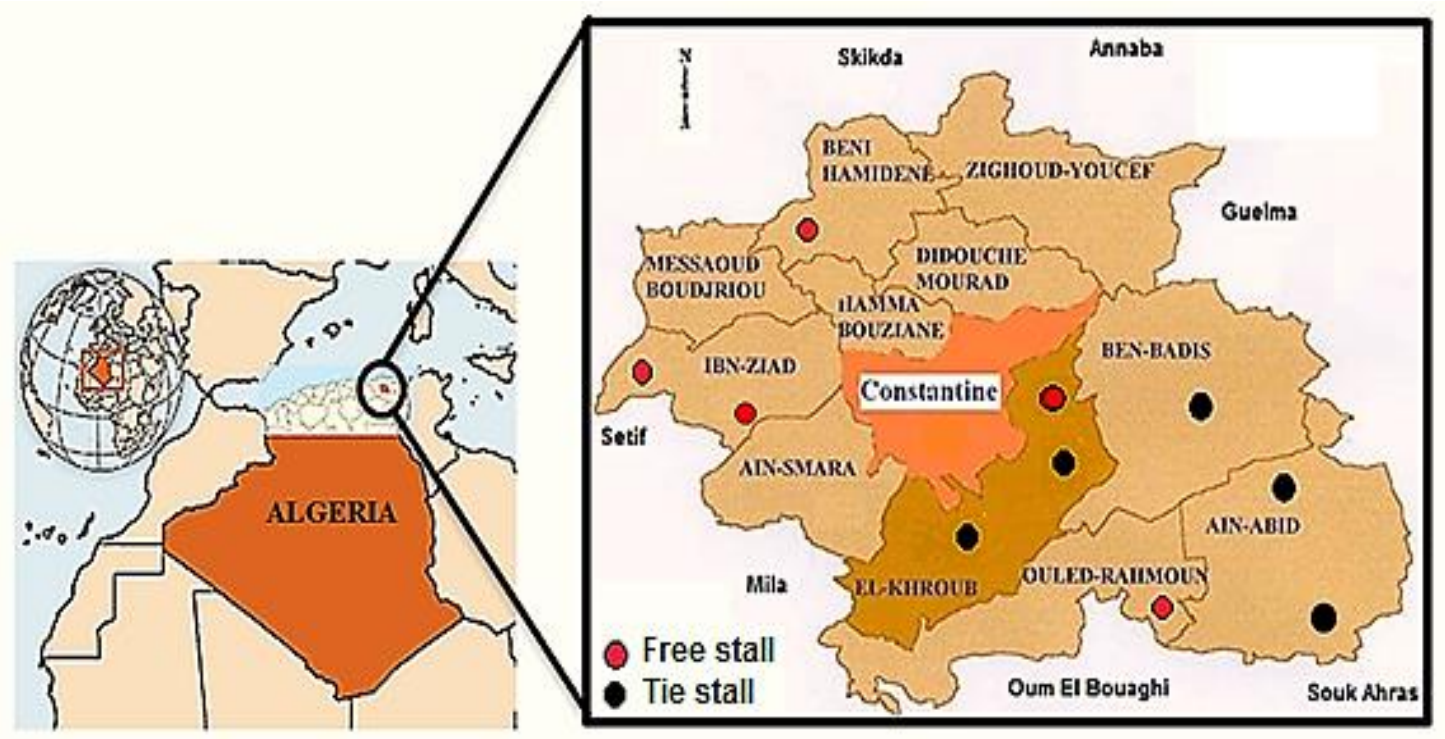

Figure 1. Geographical representation of the main municipalities in the Constantine's governorate (Northern Algeria). 


\section{Study design}

The study conducted during the winter and spring of 2018 to 2019, involved 299 cows of the Holstein and Montbeliard breeds, with 161 females housed in free stall farms and 138 females housed in tie stall farms. A total of 2093 assessments were carried out on 10 herds with an average size of $30 \pm 2$ dairy cows (Figure 1). Reproduction occurs naturally or by artificial insemination. The diet is based on silage, forage, straw and concentrate. The floor of the barns is concrete, with a slight slope, and the litter is straw-based. Some barns have geotextile mattresses in rest areas, and circulation mats in corridors. The cleaning is done by automatic scrapers, while it is manual in old buildings. Farms were selected for dairy speculation, numbers and data availability. All data were collected by the same observer and scoring is done within the hour preceding the morning milking. The analysis focused on animal cleanliness indices; leg health scores (lameness scores, aplomb and hock and knee injuries) and body score condition.

\section{Measured parameters}

\section{Cleanliness indices}

Animal cleanliness was quantified according to the objective provided by Faye and Barnouin (1985). The latter was based on the observation of the 5 regions which are: the lower part of the hind legs, the udder (seen from behind), the udder and abdomen, the ano-genital region and the thigh. For each region, a score was assigned from 0 (no soiling) to 2 (completely soiled and/or covered with a thick crust). The scores for the first 4 regions where summed, to obtain an overall score of 0 to 8 corresponding to the "individual cleanliness" index.

We also recorded the cleanliness of the thigh area which was indicative of the cleanliness of the housing. The overall score was varied from 0 to 10 . Each rating corresponds to a level of cleanliness ranging from 0 to $<2$ (very clean stall) to 8 to 10 (very dirty stall). The average of the scores obtained for each cow in the herd corresponds to the "stable cleanliness" status.

\section{Musculoskeletal health scores \\ Lameness score}

The test involves evaluating the locomotor score of cows using the Sprecher et al. (1997) method. The test must be carried out on an animal in a static position and walking on a comfortable and flat surface, while observing the position of the back and the appearance of the gait. The assigned score is between 1(normal) and 5 (severe lameness):

Score 1: Normal stands and walks normally, legs are well placed.

Score 2: Slightly lame: stands with flat back, but bends back while walking.

Score 3: Moderately lame: stands with curved back, in short legs with one or more legs.

Score 4: Lame: stands and walks with curved back, favors one or more legs but can still put weight on.

Score 5: Lame curved back, refuses to put weight on one leg, may refuse or have difficulty getting up.

\section{Plumb score}

The test consists of assessing the degree of abnormalities of the plumbs. The method is based on assessment of limb alignment and deviation (Guyot et al., 2014). The rating scale is:

Score 1: Members deflection from $0^{\circ}$ to $17^{\circ}$;

Score 2: Members deviation from $17^{\circ}$ to $24^{\circ}$;

Score 3: Deviation of members greater than $24^{\circ}$.

\section{Hock injuries score}

The hock region is observed to identify lesions and assess severity. The hock injury score is evaluated using the method described by Guyot et al. (2014). The scores are between 0 and 4:

Score 0: Normal tarsus

Score 1: Alopecia only

Score 2: Alopecia + swelling

Score 3: Alopecia + swelling $>1 / 2$ grapefruit aspect

Score 4: Alopecia + swelling $>1 / 2$ grapefruit aspect + pain

\section{Knee injuries score}

Knee injuries of cows are determined according to the charter described by Gibbons et al. (2012).

Score 0: normal carp

Score 1: No swelling but hairless area on the knee.

Score 2: Major swelling (> 2,5 cm), lesions and alopecia.

\section{Body Condition Scoring (BCS)}

To assess body condition, cows were scored on a scale of 1 to 5 , respectively for a state of emaciated: 1 , thin: 2 , medium: 3 fatty 4 and obese: 5 with quarter point (1/4) subdivision according to the method described by Ferguson et al. (1994). To refine scores, particular attention was paid to the appearance of certain areas of the body. The specific regions include the spinous and transverse processes of the lumbar vertebrae, the ileal (hook bone) and ischeal (pine 
bone) tuberosities, the ileo-sacral and ischeal-coccygeal ligaments, the tail head, and the thurl region. Fat deposits are estimated by palpation, visual inspection, or both.

A monthly body condition score was assigned to each animal, and then the scores were distributed according to physiological stages. The stages concerned were the beginning, middle and end of lactation as well as dry period. In addition, in order to determine the effect of the stall type (free or confined) on average milk production, individual milk production (kg/cow/day) was recovered after recording the data from each farm surveyed.

\section{Statistical analyses}

The data resulting from the experiment were treated through Excel tables (Microsoft 2007). The content of which was used to initially perform descriptive statistics was the Graph Pad Prism 7.00 software to calculate the mean and the standard error of the mean (S.E.M.).

The effect of fixed factors, housing (free stall, tie-stall) and season (winter, spring) of the experiment and their interaction on the various parameters studied (individual cleanliness, stable cleanliness, lameness score, plumbs score, injuries hocks and knees as well as the body score) was analyzed using the two-way ANOVA (Analysis of Variance) test (stall and season). Tukey's multiple comparisons test was carried out to test significance between means of the different subgroups. The pair-wise comparison of mean milk yield and peak lactation in the two types of housing is affected using Student's t-test. Differences were considered significant when $\mathrm{P}<0.05$. All mean values are expressed as the mean \pm S.E.M.

The correlation coefficients between the results of the various parameters indicative of the comfort of dairy cows are calculated according to the correlation test (Pearson correlation).

\section{RESULTS AND DISCUSSIONS}

\section{Individual and stable cleanliness}

The influence of the season and the type of housing on the variation of the percentages and average scores of the individual cleanliness and the cleanliness of the housing are shown in Table 1. Whatever the season and the type of stall, the rate of clean to very clean dairy cows is $73.57 \%$ (220) for the hind limb; $73.24 \%$ (219) for the udder; $62.21 \%$ (186) for the abdomen; 75.58\% (226) for the ano-genital region ( $\mathrm{P}>0.05)$ and 77.26\% (231) for the thigh $(\mathrm{P}<0.05)$.

Table 1. Percentage of dairy cows and farms cleanliness according to season and type of housing

\begin{tabular}{|c|c|c|c|c|c|c|c|c|c|c|c|c|c|}
\hline \multirow{3}{*}{\multicolumn{2}{|c|}{ Cleanliness indices }} & \multirow{3}{*}{ Score } & \multicolumn{4}{|c|}{ Free stall } & \multicolumn{4}{|c|}{ Tie-stall } & \multirow{2}{*}{\multicolumn{3}{|c|}{$\mathbf{P}$}} \\
\hline & & & \multicolumn{2}{|c|}{ Winters } & \multicolumn{2}{|c|}{ Spring } & \multicolumn{2}{|c|}{ Winters } & \multicolumn{2}{|c|}{ Spring } & & & \\
\hline & & & $\%$ & $\mathbf{n}$ & $\%$ & $\mathbf{n}$ & $\%$ & $\mathbf{n}$ & $\%$ & $\mathrm{n}$ & stall & $\begin{array}{c}\text { seaso } \\
\text { n }\end{array}$ & $\begin{array}{c}\text { stall } x \\
\text { seaso } \\
\text { n }\end{array}$ \\
\hline \multirow{5}{*}{ Notation } & Very clean & {$[0-2]$} & 14.28 & 23 & 13.66 & 22 & 6.52 & 9 & 15.21 & 21 & \multirow{5}{*}{ ns } & \multirow{5}{*}{$<0.05$} & \multirow{5}{*}{ ns } \\
\hline & Clean & {$[2-4]$} & 32.92 & 53 & 39.75 & 64 & 12.31 & 17 & 23.18 & 32 & & & \\
\hline & Little dirty & [4-6] & 34.16 & 55 & 31.05 & 50 & 19.56 & 27 & 37.68 & 52 & & & \\
\hline & Dirty & [6-8] & $11.50^{\mathrm{ab}}$ & 19 & $10.56^{\mathrm{ab}^{*}}$ & 17 & $32.60^{\mathrm{cd}^{*}}$ & 45 & $10.86^{\mathrm{cd}}$ & 15 & & & \\
\hline & Very dirty & {$[8-10]$} & $6.83^{\mathrm{ab}}$ & 11 & $4.96^{\mathrm{a} \mathrm{a}^{* *}}$ & 8 & $28.98^{\mathrm{cd}^{* * *}}$ & 40 & $13.04^{\mathrm{cd}}$ & 18 & & & \\
\hline \multicolumn{2}{|c|}{$\begin{array}{l}\text { Individual } \\
\text { cleanliness }\end{array}$} & {$[0-8]$} & $4.47^{\mathrm{a}}$ & 161 & $3.91^{\mathrm{b}^{* * *}}$ & 161 & $6.03^{* * *}$ & 138 & $5.09^{d}$ & 138 & $<0.001$ & $<0.01$ & ns \\
\hline \multicolumn{2}{|c|}{$\begin{array}{l}\text { Collective } \\
\text { cleanliness }\end{array}$} & {$[0-10]$} & $5.44^{a}$ & 161 & $4.61^{b^{* * *}}$ & 161 & $7.62^{\mathrm{e}^{* * *}}$ & 138 & $6.12^{\mathrm{d}}$ & 138 & $<0.001$ & $<0.001$ & $<0.01$ \\
\hline
\end{tabular}

a, b, c, d: Different letters in the same row indicate a significant difference; ns: No significant difference (P >0.05); ${ }^{*}$ Significant difference

$(\mathrm{P}<0.05){ }^{* *}$ High significant difference $(\mathrm{P}<0.01){ }^{* * *}$ Very high significant difference $(\mathrm{P}<0.001)$; Stall $\mathbf{x}$ season: Interaction of type of housing and season; Individual cleanliness: Dairy cows' cleanliness; Collective cleanliness: Farms cleanliness.

In our study, an overall effect between the season and the type of housing is observed for the cleanliness of the farm $(\mathrm{P}<0.01)$. The average score for dairy cow cleanliness and farm cleanliness is significantly influenced by housing type and season $(\mathrm{P}<0.001)$. In addition, we note that the seasonal factor significantly influences the cleanliness of dairy cows $(\mathrm{P}<0.01)$ and the farm $(\mathrm{P}<0.001)$. The respective rate of dirty to very dirty cows is significantly lower in free stall during the spring period $(10.65 \%$ (17) $\mathrm{P}<0.05 ; 4.96 \%$ (8) $\mathrm{P}<0.01)$ compared to cows in tie-stall during the winter period $(32.60 \%(45) \mathrm{P}<0.05 ; 28.98 \%$ (40) $\mathrm{P}<0.01)$. 
In contrast to spring, females in tie-stall are significantly dirtier in winter (5.09\% spring vs $6.03 \%$ in winter; $\mathrm{P}$ $<0.001$ ) compared to those in free housing ( $3.91 \%$ vs. $4.47 \%$; $\mathrm{P}<0.001)$. A similar effect is observed for different farms in the two respective seasons (winter and spring) (7.62\% vs. 4.61\%; $\mathrm{P}<0.001$ ).

\section{Lameness score}

The prevalence of lameness of dairy cows housed in both types of housing and in both seasons is shown in Table 2 . The frequency of lameness is influenced by the type of housing $(\mathrm{P}<0.001)$ but not by the season $(\mathrm{P}>0.05)$. During spring, the number of healthy females (score 0 and 1 ) with a normal gait are significantly more abundant in free stall compared to those in tie-stall (73.91\% (119) vs. 56.52\% (78); P <0.001). On the other hand, we observe the absence of cows suffering from severe lameness (score 4 and 5 ) housed in free-stall compared to those in tie-stall ( $0 \%$ vs. $9.42 \%$ (13); $\mathrm{P}<0.001)$. In general, the season $(\mathrm{P}<0.001)$ and the type of housing $(\mathrm{P}<0.01)$ have a significant influence on the mean lameness score. In contrast, to tie-stall housing and the winter season, females from free stall farms are the best classified and have a significantly low average lameness score during spring period $(1.23 \pm 0.04 ; \mathrm{P}<0.001)$.

Table 2. Prevalence of dairy cow lameness in relation to season and type of housing (percentage and average score: mean \pm S.E.M.)

\begin{tabular}{|c|c|c|c|c|c|c|c|c|c|c|c|c|}
\hline \multirow{3}{*}{\multicolumn{2}{|c|}{ Lameness score }} & \multicolumn{4}{|c|}{ Free stall } & \multicolumn{4}{|c|}{ Tie-stall } & \multirow{2}{*}{\multicolumn{3}{|c|}{$\mathbf{P}$}} \\
\hline & & \multicolumn{2}{|c|}{ Winters } & \multicolumn{2}{|l|}{ Spring } & \multicolumn{2}{|c|}{ Winters } & \multicolumn{2}{|c|}{ Spring } & & & \\
\hline & & $\%$ & $\mathbf{n}$ & $\%$ & $\mathbf{n}$ & $\%$ & $\mathbf{n}$ & $\%$ & $\mathbf{n}$ & stall & season & $\begin{array}{l}\text { stall } x \\
\text { season }\end{array}$ \\
\hline Normal leg & & & & & & & & & & & & \\
\hline Slightly lame & 1 & $54.65^{\mathrm{ab}}$ & 88 & $61.49^{\mathrm{a}^{* * *}}$ & 99 & $50^{\mathrm{abc}}$ & 69 & 46.37 & 64 & & & \\
\hline Moderately & 2 & $34.16^{\mathrm{ab}^{*}}$ & 55 & $34.61^{b}$ & 55 & $28.26^{\mathrm{abc}}$ & 39 & 19.56 & 27 & & & \\
\hline lame & 3 & $7.45^{\text {cde }^{* *}}$ & 12 & $4.35^{\mathrm{b}}$ & 7 & $13.04^{\mathrm{abc}}$ & 18 & 14.49 & 20 & $<0.001$ & ns & ns \\
\hline Lame & 4 & $3.72^{\text {cde }^{* * * *}}$ & 6 & $0^{\mathrm{b}}$ & 0 & $8.69^{\mathrm{de}^{*}}$ & 12 & 14.49 & 20 & & & \\
\hline $\begin{array}{l}\text { Lame curved } \\
\text { back }\end{array}$ & 5 & $0^{\mathrm{cde}^{* * *}}$ & 0 & $0^{\mathrm{b}}$ & 0 & $0^{\mathrm{de} \mathrm{e}^{* *}}$ & 0 & 5.07 & 7 & & & \\
\hline Healthy cow & [0-1] & $52.17^{\mathrm{ab}}$ & 84 & $73.91^{\mathrm{a}}$ & 119 & 61.59 & 85 & $56.52^{\mathrm{ab}^{*}}$ & 78 & & & \\
\hline Light lameness & [2-3] & $41.61^{\mathrm{ab}}$ & 67 & $26.09^{\mathrm{bc} * *}$ & 42 & 28.98 & 40 & $34.05^{\mathrm{ab}}$ & 47 & $<0.001$ & ns & ns \\
\hline Severe lameness & [4- 5] & $6.21^{\mathrm{bc} * *}$ & 10 & $0^{\mathrm{b} c^{* * *}}$ & 0 & 9.42 & 13 & $9.42^{\mathrm{bc}^{*}}$ & 13 & & & \\
\hline \multicolumn{2}{|c|}{ Average score } & $1,49 \pm 0,06^{\mathrm{eg}^{* *}}$ & 161 & $1.23 \pm 0.04^{\mathrm{e}^{\mathrm{e}} \mathrm{e}^{2 * x}}$ & 161 & $1.91 \pm 0.12^{\mathrm{gh}}$ & 138 & $1.67 \pm 0.11^{\mathrm{gh}}$ & 138 & $<0.01$ & $<0.001$ & ns \\
\hline
\end{tabular}

a, b, c, d: Different letters in the same column indicate a significant difference; $\mathbf{e}, \mathbf{f}, \mathbf{g}, \mathbf{h}$ : Different letters in the same row indicate a significant

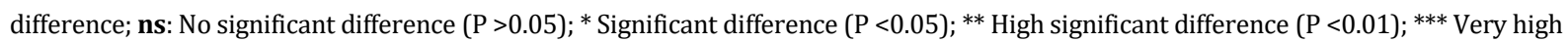
significant difference $(\mathrm{P}<0.001)$; Stall $\mathbf{x}$ season: Interaction of type of housing and season.

\section{The leg health score}

Table 3 shows the different percentages and health scores of the locomotor system indicating the comfort of dairy cows (score of lesions of the plumbs, hocks and knees). The season had a significant effect on the level of cows ( $\mathrm{P}$ $<0.001$ ). The highest percentage of cows with a $17^{\circ}$ to $24^{\circ}$ deflection of the plumb (score 2 ) is registered during spring period in the opposite to the winter period (57.97\% (80) vs. 31.67\% (51); P <0.001). In winter, more than $23 \%(33)$ of cows housed in tie-in housing suffer from deviations in plumbs $>24^{\circ}$ (score 3$)(\mathrm{P}>0.05)$. Moreover, the average score of plumb lesions is significantly influenced by the type of housing $(\mathrm{P}<0.05)$. We also note that in winter, dairy cows housed in free stall housing have the highest score of plumb lesions compared to those in tie-stall $(1.86 \pm 0.05$ vs.1.65 $\pm 0.06 ; \mathrm{P}<0.05)$. Moreover, a significant effect of housing $(\mathrm{P}<0.001)$ is observed on the score of plumb, injuries, but also on the percentage and the score of the hocks and knees injuries in females housed in free stall. An overall effect (stable $x$ seasons interaction) was noted on the percentages of cows injured at the hocks $(\mathrm{P}<0.05)$ (Table 3). During spring, out of all the cows surveyed, we recorded a significantly low rate of females with normal tarsus (score 0) belonging to the confined housing systems (35.50\% (49); P <0.001). For the same period (spring), cows in both housing types suffer the most from alopecia and tarsal pain swelling (score 4) compared to cows in free housing in winter $(8.07 \%$ (13) vs. 0 ; P >0.05). Nevertheless, the average score of hock injuries is significantly higher for cattle in stalled housing and especially in winter $(1.55 \pm 0.09$; $\mathrm{P}<0.001)$. Thus, the type of housing influences significantly the rate of knee injuries $(\mathrm{P}<0.001$ ) (Table 3 ). We note a small percentage of females with lesions and 
alopecia at the knee level (score 2) in tie-stall housing unlikely to the free housing (1.44\% (2) vs. 11.80\% (19); P <0.001). Cows housed in the tie-stall system had a significant higher average knee injury score compared to those in the free system $(1.64 \pm 0.04 \mathrm{vs} .0 .77 \pm 0.05 ; \mathrm{P}<0.001)$.

Table 3. Percentage and average score (mean \pm S.E.M.) of leg health of dairy cows (deflection of plumbs and injuries of hocks and knees)

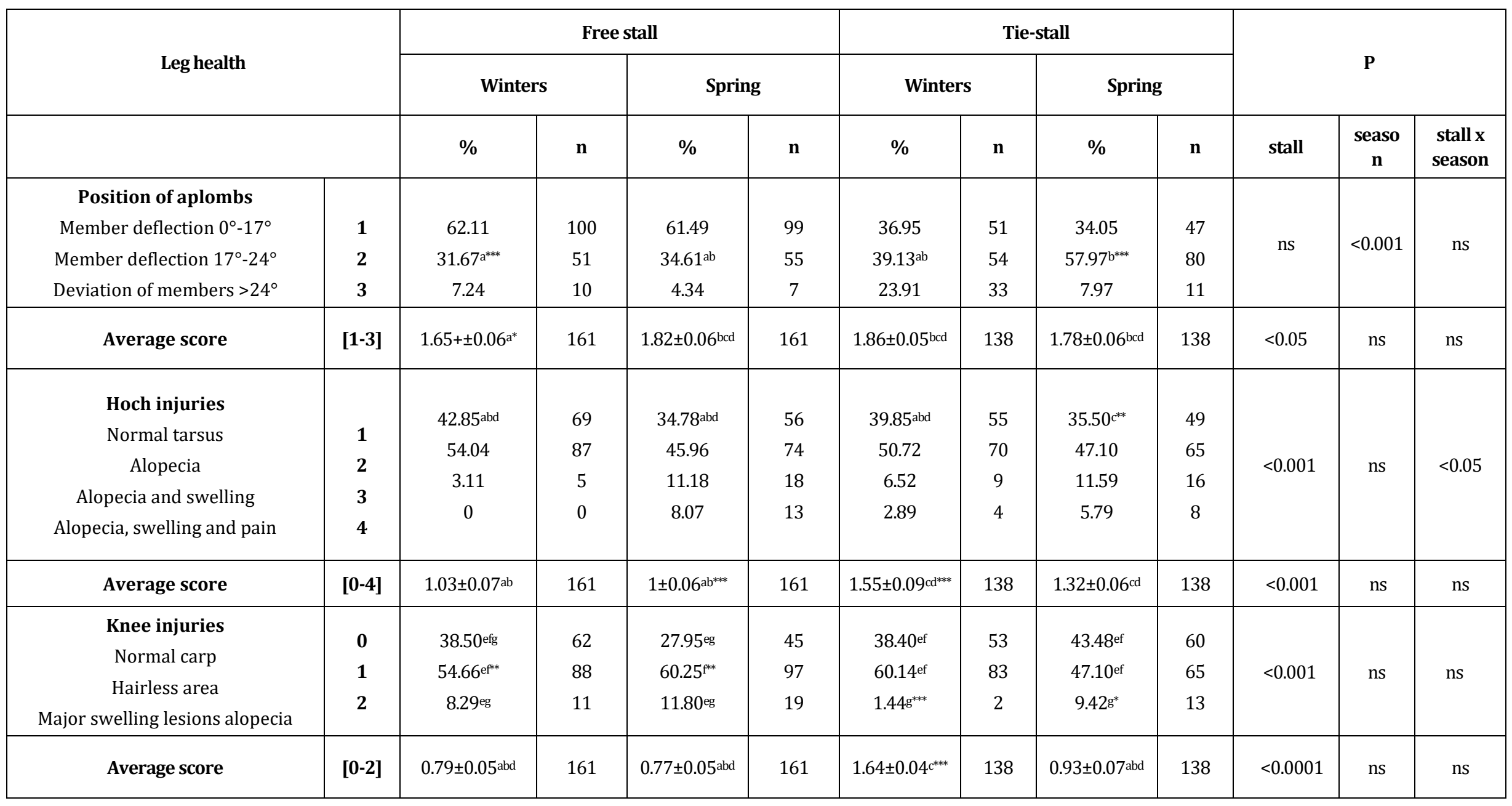

a, b, c, d: Different letters in the same line indicate a significant difference; $\mathbf{e}, \mathbf{f}, \mathbf{g}, \mathbf{h}$ : Different letters in the same column indicate a significant difference; $\mathbf{n s : ~ N o ~ s i g n i f i c a n t ~ d i f f e r e n c e ~ ( P ~}>0.05)$; *

Significant difference $(\mathrm{P}<0.05)$; ** High significant difference $(\mathrm{P}<0.01)$; *** Very high significant difference $(\mathrm{P}<0.001)$; Stall $\mathbf{x}$ season: interaction of type of housing and season. 


\section{Body score condition and milk production}

The change in the body condition score of dairy cows in different farms is not influenced by the type of housing (P $>0.05)$. However, the effect of the physiological stage is highly significant $(\mathrm{P}<0.001)$ (Table 4$)$.

Table 4. Effect of housing type on the body condition of dairy cows at different physiological stages

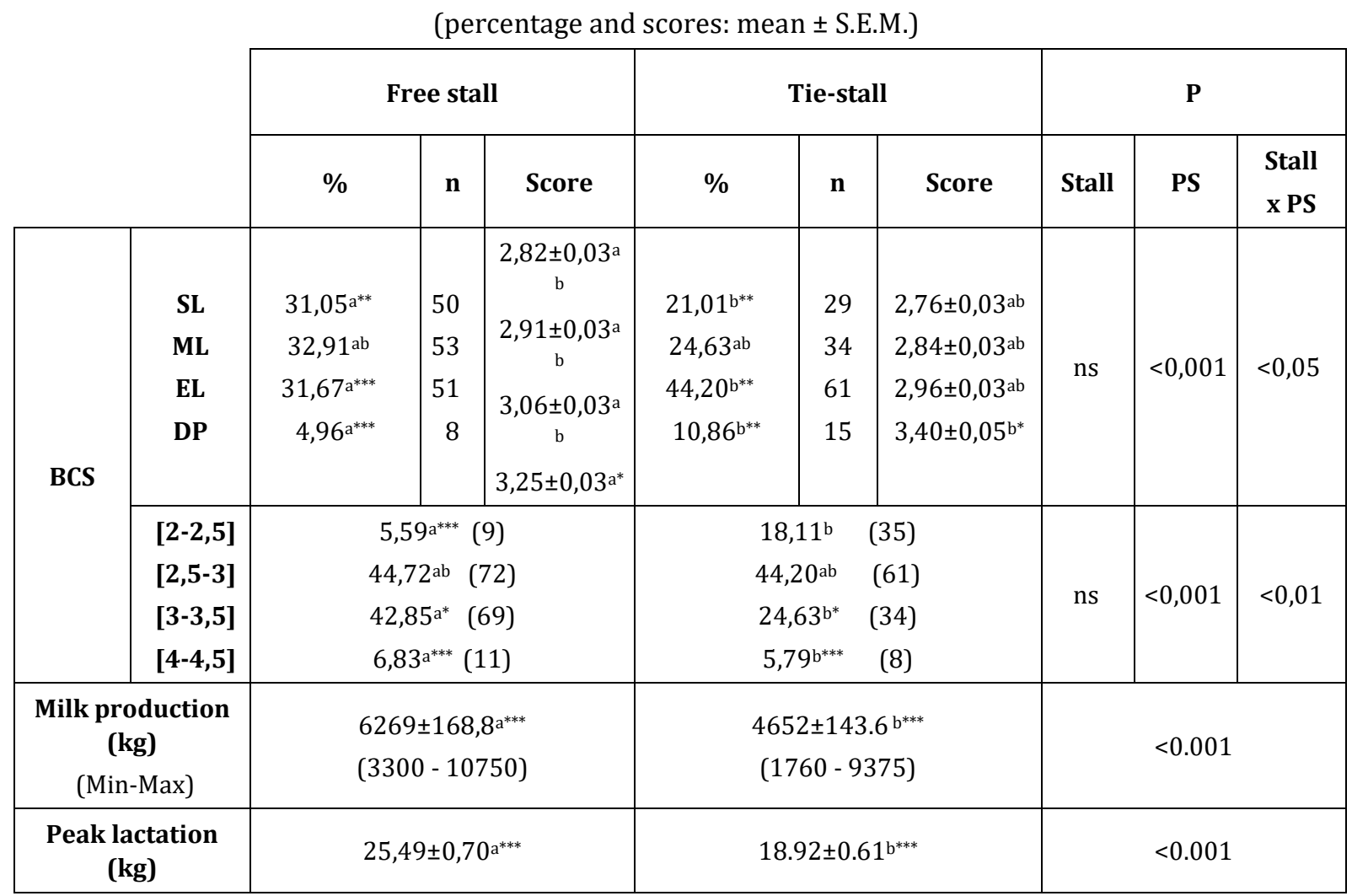

a, b, c, d: The different letters in the same line indicate a significant difference; BCS: Body score condition; SL: Start of lactation; ML: Mid lactation; EL: End of lactation; DP: Drying period; PS: Physiological stage; Stall x SP: Interaction of type of housing and physiological stage.

In early lactation, the percentage of cows with a body condition score ranging from 2.76 to 2.82 is significantly high in those in free stalls (31.05\% (50) vs. $21.01 \%$ (29); P <0.001). On the other hand, females in the end of lactation, this respective rate has been significantly reversed (31.27\% (51) vs. $44.20 \%(61)$; $\mathrm{P}<0.001)$ with a non-significant increase in body score at $3.06 \pm 0.03(\mathrm{P}>0.05)$.

In dry period, cows in tie-stalls with high body condition score $(3.40 \pm 0.05 ; \mathrm{P}<0.05)$ have a significant high percentage compared to dry cows in tie-stall $(10.86 \%$ (15) vs. 4.96\% (8); P <0.001). Even the type of housing does not have an influence on the body condition, while an interaction effect between the type of housing and the physiological stage of dairy cows was shown to be very significant $(\mathrm{p}<0,01)$.

The high frequency of females from loose housing in early and mid-lactation, tells us about the average milk production of these cows compared to those from tie-stall housing $(6269 \pm 168.8 \mathrm{~kg}$ vs. $4652 \pm 143.6 \mathrm{~kg} ; \mathrm{P}<0.001)$. The percentage of thin cows (score 2-2.5) housed in tie-stall is significantly higher than those housed in free stall $(18.11 \%$ (35) vs. 5.59\% (9); $\mathrm{P}<0.001)$. Moreover, the rate of low-fat females (score 3-3.5) is significantly high in the extensive system than in the intensive system (6.83\% (11) vs. $24.63 \%$ (34); $\mathrm{P}<0.05)$. While the average amount of milk produced by free-stall cows is significantly higher $(6269 \pm 168.8 \mathrm{~kg} ; \mathrm{P}<0.0001)$ with a considerable high lactation peak $(25.49 \pm 0.70 \mathrm{~kg}$; $\mathrm{P}<0.0001)$.

\section{Cleanliness}

According to the results reported in Table 1, the percentage of dirty to very dirty cows is significantly high for females in tie-stall housing compared to those in free stall $(\mathrm{P}<0.001)$. Our results are in agreement with Popescu et al. (2014b) work which suggests that the rate of dirty cows is significantly higher in tie stalls housing than those in free stalls, especially at the lower legs (50.72 vs. $33.47 \%$ ); udder (20.54 vs. $27.45 \%$ ), flank and thigh (25.23 vs. 43.31\%). In addition, Belkheir et al. (2015), by assessing the individual cleanliness of 134 Algerian farms during the winter season, recorded that $44 \%$ of cows were not very dirty, $36 \%$ were dirty, $13 \%$ were clean but observe only 
$7 \%$ in the category of very dirty. According to Bastien et al. (2006), the state of dirt of bovine leathers is the highest in winter (around January-February) with proportions of dirty animals reaching the rate of more than one out of five bovines under breeding conditions in France. This latter constant was also observed in Benatallah et al. (2015) studies, who reported a high frequency of udder dirt (62.6\%), hindquarters (60.6\%) and hind limbs (60.6\%). Indeed, the increase in the frequency of dirt in animals would be influenced by the nature of the soil, the fecal consistency, the drainage system, the frequency of cleaning as well as the dominance of the housing system hampered (53\% of Algerian farms are in zero pasture). These main factors are a permanent source of mental stress and physical distress (diseases, injuries...), impaired productivity, health and welfare of livestock. In addition, Abdelguerfi and Zeghida (2005) note that the majority of Algerian dairy farms are of the confined housing type; this would be due to urbanization and the use of agricultural land by urban people, reducing the access of animals to pastures and endangering wildlife heritage and national food security.

Moreover, we noted that individual cleanliness is strongly correlated with the cleanliness of the stall $(\mathrm{r}=0.85$; $\mathrm{P}$ $<0.001$ ) (Table 5).

Table 5. Correlation matrix of the different parameters indicating the comfort of dairy cows studied in Eastern Algeria

\begin{tabular}{|c|c|c|c|c|c|c|c|}
\hline $\mathbf{r}^{\mathbf{p}}$ & $\mathbf{B C S}$ & $\begin{array}{c}\text { Individual } \\
\text { cleanliness }\end{array}$ & $\begin{array}{c}\text { Stall } \\
\text { cleanliness }\end{array}$ & Lameness & Plumbs & $\begin{array}{c}\text { Hock } \\
\text { injuries }\end{array}$ & $\begin{array}{c}\text { Knee } \\
\text { injuries }\end{array}$ \\
\hline $\begin{array}{c}\text { Individual } \\
\text { cleanliness }\end{array}$ & $-0,03^{\text {ns }}$ & & & & & & \\
\hline $\begin{array}{c}\text { Stall } \\
\text { Cleanliness }\end{array}$ & $-0,06^{\text {ns }}$ & $\mathbf{0 , 8 5 ^ { * * * }}$ & & & & & \\
\hline Lameness & $0,02^{\text {ns }}$ & $-0,04^{\text {ns }}$ & $0,002^{\text {ns }}$ & & & & \\
\hline Plumbs & $-0,01^{\text {ns }}$ & $-\mathbf{0 , 9 2}^{* * *}$ & $\mathbf{0 , 8 9}^{* * *}$ & $-0,04^{\text {ns }}$ & & & \\
\hline Hock injuries & $\mathbf{- 0 , 9 0}^{* * *}$ & $-0,02^{\text {ns }}$ & $-0,04^{\text {ns }}$ & $-0,07^{\text {ns }}$ & $-0,07^{\text {ns }}$ & & \\
\hline Knee injuries & $\mathbf{- 0 , 8 1}^{\text {*** }}$ & $0,02^{\text {ns }}$ & $\mathbf{- 0 , 7 8 * *}^{* *}$ & $-0,07^{\text {ns }}$ & $-0,01^{\text {ns }}$ & $\mathbf{0 , 9 0}^{* * * *}$ & \\
\hline $\begin{array}{c}\text { Milk } \\
\text { production }\end{array}$ & $0,05^{\text {ns }}$ & $\mathbf{0 , 8 1 ^ { * * }}$ & $0,09^{\text {ns }}$ & $\mathbf{0 , 8 2}^{* *}$ & $-0,08^{\text {ns }}$ & $0,01^{\text {ns }}$ & $0,04^{\text {ns }}$ \\
\hline
\end{tabular}

r: Correlation coefficient; ns: No significant difference $(\mathrm{P}>0.05)$; ${ }^{*}$ Significant difference $(\mathrm{P}<0.05)$; ${ }^{* *}$ High significant difference $(\mathrm{P}$ $<0.01)$; ${ }^{* * *}$ Very high significant difference $(\mathrm{P}<0.001)$; BCS: body score condition.

Results from Table 5 were consistent with the findings of Bouraoui et al. (2014) studies which stated that cleanliness of the hind limbs, udder and general conditions are strongly correlated. Therefore, the health status of the udder is influenced by any variation in the cleanliness of these sites.

Several authors claim that the high rate of dirty cows was proven to be linked to a degraded environment of the animal (Whay et al., 2003; Andreasen and Forkman, 2012; Popescu et al., 2014a); the non-compliance with the recommendations of cleaning and daily change of the litter, a improper length of the stall, a wet sleeping area, slippery, without or with a thin litter indicate poor animal health conditions.

According to the correlation matrix (Table 5), we note that individual cleanliness is inversely related to tarsal damage $(r=-0.92 ; P<0.001)$ but is positively related to milk production $(r=0.81 ; P<0.01)$. Andreasen and Forkman (2012) argued that cleanliness, weathering, lameness and milk production are important indicators of cow wellbeing. These authors reported that the use of sand as a stall surface is associated with improvment of the animals' well-being.

Accordingly, Bastien et al. (2006) studies showed that cleanliness of cows is directly related to that of litter, which depends on the amount of straw and the frequency of mulching. Furthermore, Belkheir et al. (2015) reported that at the level of all the surveyed farms, the amount of straw and the frequency of mulching were insufficient. This is due to the high price of straw which is considered to be a main obstacle. In the other hand, Abdelguerfi and Zeghida (2005) reported that throughout the Algerian territory and during a long period of the year, straw is mainly used as food and not as litter, because of its high price.

In our study, during the winter period, we noticed that the females housed in tomporary housing were significantly dirtier than those in free housing $(\mathrm{P}<0.0001)$. Our results are in agreement with those reported by Hristov and Relić (2009) who noted extreme cold conditions and higher humidity can cause difficulties in maintaining animal hygiene during winter. Ostojić-Andrić et al. (2017) postulated that the well-being of cows is significantly better in the summer season than winter season as in winters due to the presence of manure on the 
body of cows, humidity of the skin might get increased causing a decrease in the body temperature leading to immunosuppression, and consequently, the appearance of diseases. Moreover, open buildings for bedding are likely to be more exposed to air, which reduces its heat and moisture, thus limiting the proliferation of germs (Levesque, 2004). Some cows react to an unfavorable microbial environment and had an increasing cell count (Mtaallah et al., 2002; Schreiner and Ruegg, 2003) without the appearance of clinical mastitis (Coulon et al., 1996; Bouraoui et al., 2014). It would therefore be unacceptable to have more than $20 \%$ of the herd at a score of 3 or 4 (dirty cows) because soiled udders increase the risks of mastitis (Sillett et al., 2003).

Our results showed that cleanliness of the housing is positively correlated with the health scores of the plumbs $(r=0.89 ; \mathrm{P}<0.001)$. Moreover, it is negatively related to the injuries of the knees $(r=-0.78 ; \mathrm{P}<0.01)($ Table 5$)$, which is consistent with the work of Kathambi et al. (2019) which recorded average stall, udder and thigh cleanliness scores of 2.4; 1.9 and 2.5 respectively. These authors have also demonstrated carpal and hock lesions that occured in $13 \%$ and $15 \%$ of cows on small dairy farms in Kenya. Norring et al. (2008) and Andreasen and Forkman (2012) indicated that cows housed in open sand-covered barns are cleaner than cows housed in barns where rubber mats, mattresses or straw are used as a litter. Thus, Cook in his study (2003) argued that using sand as bedding has the advantage of bringing the animal to cushioning and adapting to shock, which increases the decubitus time by improving cow comfort. It can also improve surface traction in both stalls, where it can help cows getting up and down, and in hallways, where sand would help prevent slipping on smooth concrete (Cook and Nordlund, 2009).

\section{Lameness}

In our study, the frequency of lame cows was not influenced by the season $(P>0.05)$ (Table 2 ). These results are concordant with those of Shepley et al. (2019b) which assessed the impact of locomotor activity (number of steps) on the lameness score of dairy cows. However, these authors did not indicate any significant differences in the number of lame animals between winter and summer periods in the two types of tie $(\mathrm{P}=0.61)$ and free stall $(\mathrm{P}=$ 0.31).

According to Cook (2003), there is no significant seasonal difference between tie-stalled herds (summer: 19.6\%; winter: 19.7\%), but in free-stall herds, mean prevalence of lameness in winter was significantly higher than in summer (27.8 vs. $22.8 \%$; $\mathrm{P}=0.004$ ). As a result, females housed in free-stall housing were the highest ranked and had a significantly lower mean lameness score compared to cows in tie-stall $(\mathrm{P}<0.001)$.

Analysis of the Pearson correlation indicated that the effect of the lameness score was positively correlated with milk production $(\mathrm{r}=0.82$; $\mathrm{P}<0.01$ ) (Table 5). Our results are in agreement with the work of Brochart and Fayet (1981) which demonstrated the presence of a close relationship between the level of milk production and the rate of lameness; Indeed, each increase in milk production of one liter compared to the average of the first three milk controls were accompanied by a 5.8\% increase in the frequency of lameness. This increase is particularly due to metabolic leg pathologies, as their frequency increased from $4.4 \%$ to $17.4 \%$ when milk production per day increased from $15-16 \mathrm{~kg}$ to $25-26 \mathrm{~kg}$.

In point of fact, for the bovine species, most epidemiological surveys agree that lameness is recorded as the third highest in the hierarchy of pathological disorders, after infertility and mastitis (Faye and Barnouin, 1988; Sprecher et al., 1997). Moreover, Whay et al. (2003) and Bernardi et al. (2009) argued that lameness is one of the major problems faced in increasing milk production, as well as a cause of pain and discomfort to dairy cows represented by a decrease of mobility and alteration of normal behavior.

It is known that foot pathology is more common during the stabling period than during the grazing period (Brochart and Fayet, 1981). This effect is linked to the confinement of animals during the winter period and to the middle stage of lactation during the same season, the maximum number of cases are generally recorded in the third month of lactation (Faye and Fayet, 1986).

In our study, we observed the absence of cows with severe lameness (score 4 and 5) housed in free-stall compared to those in tie-stall $(\mathrm{P}<0.001)$. During spring, free-stall females had a significant low lameness score compared to those registered during winter months housed in a tie-stall $(\mathrm{P}<0.001)$. Our results are in agreement with those shown by Popescu et al. (2013) who indicated that in summer, pasture outflows are positively correlated with the higher number of steps in both free stall $(\mathrm{r}=0.59 ; \mathrm{P}<0.01)$ and tie stall $(\mathrm{r}=0.59 ; \mathrm{P}<0.01)$. Similarly, Shepley et al. (2019a) noted that the most active cows on farms in the winter more often access pastures in the summer, confirming that these cows had a greater incentive to move. It has been shown that significantly higher access to pasture in open stall systems (Olmos et al., 2009) facilitated the movement and transition of the cow from standing to lying in relation to tied housing conditions (Dohme-Meier et al., 2014; Popescu et al., 2014a; Shepley et al., 2019a). Conversely, during periods of hampered housing, cows confined on farms after a period of free access to pasture may result in a marked difference in locomotor activity.

Hernandez-Mendo et al. (2007) noted that the improvement in gait is the result of pasture providing a more comfortable standing surface than the concrete floor sliding inside the farm. This latter study also suggested a longer period of pasture access for lame cattle, which would optimize milk production and fertility in a long 
term. However, Bernardi et al., (2009) argued that this suggestion is not a practical solution for some producers where pasture availability is seasonal.

\section{Injuries}

In our study, the season had a significant effect on the rate of cows suffering from leg injuries $(\mathrm{P}<0.001)$. We also showed that during spring, a high percentage of females have lesions on the plumbs (score 2). Besides, cows with severe lameness were those with lesions of the plumb and integuments (score 3$)(P<0.001)$. Our results are concordant with the work of Potterton et al. (2011) and Burow et al. (2013) which reported a significant effect of lameness on the risk of hock joint damage. According to Chapinal et al. (2010), the pain caused by lameness brought cows to spend more time lying down and is therefore exposed to the sleeping surface for longer periods than cows on pasture. In fact, Crump et al. (2019) demonstrated that pastures provide a comfortable surface and reduces competition for sleeping space. In addition, cows on pasture would walk farther, with potential benefits to their physical health and psychological well-being.

Thus, a positive interaction is shown between knee injuries and hock injuries ( $\mathrm{r}=0.80 ; \mathrm{P}<0.01)$. In contrast, knee injuries were negatively correlated with farm hygiene $(r=-0.78 ; \mathrm{P}<0.01)$. Animals housed in open sandcovered stalls had less severe hock injuries such as plaques and glabrous wounds (Vokey et al., 2001; Lombard et al., 2010; Andreasen and Forkman, 2012). According to Fulwider et al. (2007), fine-grained sand is less abrasive, resulting in less glabrous areas at the knees and less joint damage to the tarsus and the calcium tuber.

Our results also demonstrated that the score of plumbs $(\mathrm{P}<0.001)$ is influenced by the housing type as well as the percentage and score of injured females at the hocks and knees. An overall effect (stall x season) is shown on the percentages of injured cows to hocks $(\mathrm{P}<0.05)$ (Table 3$)$. These findings are similar to those reported by Burow et al. (2013), reporting that out of 3148 dairy cows studied, $47.3 \%$ had alopecia, lesions or swelling in the hock integument, while $20.1 \%$ of which had severe lesions with pain.

According to the correlation matrix, the achievement of plumbs was negatively related to the cleanliness score of dairy cows ( $\mathrm{r}=-0.92 ; \mathrm{P}<0.001)$ and the cleanliness score of farms ( $\mathrm{r}=0.89 ; \mathrm{P}<0.001)$ (Table 5). Keil et al. (2006) works showed that the prevalence of hock lesions (2.1 scabs per cow and between 0.3 and 4.1 scabs per farm) in Swiss dairy cows is influenced by the type of bedding (straw being better than other materials). According to the same study, these lesions were negatively associated with the duration of outdoor exercise and positively associated with their frequencies.

Burow et al. (2013) reported that an increase in the number of daily grazing hours would reduce hair loss, lesions and squat swelling in Danish grazing herds. Besides, Rutherford et al. (2008) showed that a higher percentage of cows with hock swelling were observed in large herds compared to small British herds. These same authors stated that free-stall herds (more than 50 cows) in straw pens, have hock (alopecia and lesions) while swelling decreases with the increase in the number of months with summer pasture. With the increase in the number of days in winterbound housing, European dairy cows housed in free housing (more than 161 cows) have alopecia and sometimes ulcers in the joint of the hock (Potterton et al., 2011).

However, when comparing free-stall and tied-stall herds, Haskell et al. (2006) has indicated a reduction in carpal tegument alterations but not in the hock joint. Keil et al. (2006) suggested that a minimum of 50 hours spent outdoors over a 4-week period is required to have a marked outcome on the prevalence of hock injuries.

\section{BCS (Body condition score)}

The BCS reflects food management and its appropriate evolution over the different periods of lactation, which are closely related to milk yield, as evidenced by Buckley et al. (2003). In our study, the housing type did not affect the variation in overweight status of individual dairy cows $(\mathrm{P}>0.05)$. Nevertheless, we demonstrated that the rate of early lactation females from free-stall farms with the lowest body condition score $(2.82 ; \mathrm{P}<0.001)$ were those with the highest milk yield $(\mathrm{P}<0.001)$. These results are consistent with De Vries et al. (2011) which assessed the influence of body condition on milk production and find that the lower the BCS, the higher the milk yield. Moreover, Benatallah et al. (2015) reported that out of the 95 Algerian dairy farms surveyed, 81 farms contained very lean cows $(\mathrm{BCS}<2)$ with an average prevalence of $33.1 \%$ ranging from $5.8 \%$ to $51.9 \%$.

M'hamdi et al. (2014), in evaluating the welfare of Holstein cows in some dairy farms in Tunisia, observed $50 \%$ of lactating cows with a score of 2.5 and $65 \%$ of dry cows have a score of 2.75 . These works also asserted that the regular assessment of the body condition score must make it possible to correct, if necessary, the inadequacies between intakes and food requirements, particularly during critical periods of drying up and postpartum. Therefore, the dry period should ideally correspond to a stabilization phase of the status note up to calving around 3.5 points. According to Studer (1998), a descent in body condition score of about 1.0 during lactation is considered normal. A perfect body condition score is 3.0.

Furthermore, Gergovska et al. (2012) indicated that the average milk yield of Holstein cows classified as nervous or very nervous was higher than the milking yield average of calm animals. The reactions of the more nervous cows would also have a more aggressive behavior in feeding (dominant cows), which gives them more time for taking food. 
However, the body condition score was negatively correlated with knee injuries ( $\mathrm{r}=-0.81$; $\mathrm{P}<0.01)$ and tarsal joint impairment ( $r=-0.90 ; \mathrm{P}<0.001$ ) (Table 5). This finding is in agreement with Huxley (2013) study, who reported that joint damage would result in a decrease in body condition scores due to a decrease in ingestion, which in turn is related to a reduction in travel time. This may be explained by the fact that a body condition is both a cause and a consequence of lameness in dairy cows.

\section{Milk production}

Several studies show that farms with the highest milk yield generally coincide with those with the largest sizes and better facilities; feeding management practices that tend to offset the consequences of high yields could have a positive effect on cattle health (Bugueiro et al., 2020). Cows in facilities with sand in free stalls had significantly higher milk yield compared to cows housed in facilities with carpets (Andreasen and Forkman, 2012).

From Table 4, we confirmed that free-stall cows with the highest body score (between 3 and 3.5) are those with higher milk yield $(\mathrm{P}<0.001)$ and significantly higher lactation peak $(\mathrm{P}<0.001)$. Our results agree with the work reported by Bugueiro et al. (2020) which found that milk production is associated with the absence of prolonged hunger. These authors recorded an increase of $22.33 \mathrm{~kg}$ per unit of body score. Each unit increase in the score for a good diet is associated with a $26.49 \mathrm{~kg}$ increase in milk production. On the other hand, Benatallah et al. (2015) estimated that a $50 \%$ ad libitum water restriction would immediately reduce milk performance with a loss of $5 \mathrm{~kg}$ of milk per day. We also found a positive correlation between milk production, the incidence of lameness ( $\mathrm{r}=0.82$; $\mathrm{P}<0.01)$ and the individual cleanliness of dairy cows $(\mathrm{r}=0.81 ; \mathrm{P}<0.01)$ (Table 5). In a similar study by Bouraoui et al. (2014), they demonstrated a significant correlation $(r=0.9)$ between the cleanliness of the dairy cow and the mammary health of Tunisian dairy cows where the risk of mastitis is significant. These authors reported average milk losses due to high cell numbers estimated at $8.29 \%$ of milk production or $553 \mathrm{~kg}$ milk/year per cow.

Subclinical udder infections are not often appreciated by the breeder and represent $95 \%$ to $98 \%$ of cases of mastitis (Mtaallah et al., 2002) and can affect up to $25 \%$ of cows at any time of lactation. They are considered to be among the leading causes of involuntary culling of dairy cows (Tsuruta et al., 2004).

Dairy yield variables are associated with several animal welfare indicators, namely, food, housing and health. Good health, in particular, the absence of joint injuries and the absence of disease are positively associated with milk production (Coignard et al., 2014). Difficult calving, placental retention or post-partum metabolic diseases are known to reduce milk yield (Hand et al., 2012; Raboisson et al., 2014; Sundrum, 2015).

\section{CONCLUSION}

In our study, we demonstrated the strong influence of the housing system type and the season variation on the welfare of dairy cows in eastern Algeria. Accordingly, to the obtained results, we can confirm the hypothesis of the research, namely that dairy cows housed in free housing and in the spring season have a better quality of welfare than those in the tie housing system and in the winter season. Free-stall females are significantly cleaner and have free access to food and daily exercise at pasture, resulting in low levels of lameness and limb injuries. While, the lack of cleanliness, the high frequency of severe lameness and the inadequate management practices in farms with confined housing have led to the deterioration of the body condition of dairy cows, which have resulted in a negative impact on their milk yield. It is recommended that the implementation of appropriate measures to address housing system issues can significantly improve animal welfare.

\section{Conflicts of Interest}

The authors declare that they have no conflict of interest.

\section{REFERENCES}

1. Abdelguerfi A, Zeghida A. Use of fertilizers by cultivation in Algeria. Food and Agriculture Organization, Rome. Italy. Edition 2005; 56. ftp ://ftp.fao.org/docrep/fao/008/y5953f/y5953f00.pdf

2. Allane M, Ghozlane F, Temim S, Bouzida S. Dairy performance and animal welfare on farms in the wilaya of TiziOuzou (Algeria). Livest Re Rural Dev. 2011; 23(5).

3. Andreasen SN, Forkman B. The welfare of dairy cows is improved in relation to cleanliness and integument alterations on the hocks and lameness when sand is used as stall surface. J Dairy Sci. 2012; 95(9):4961-4967. doi:10.3168/jds.2011-5169.

4. AU-IBAR (African Union-Inter african Bureau for Animal Resources). AU-IBAR framework for mainstreaming livestock in the CAADP pillars. AU-IBAR, Nairobi; 2010.

5. Bastien D, Lucbert J, Cartier P. The cleanliness of cattle at the slaughterhouse: status report, explanatory factors and scoring tool. Ruminant $\quad$ Research $\quad$ Meetings. $2006 ;$ http://www.journees3r.fr/IMG/pdf/2006 10_qualite_05_Bastien.pdf 
6. Belkheir B, Ghozlane F, Benidir M, Bousbia A, Benahmed N, Agguini S. Dairy production, breeding practices and characteristics of milk in dairy cattle farms in the mountains of Kabylie, Algeria. Livest Re Rural Dev. 2015; 27(8).

7. Benatallah A, Ghozlane F, Marie M. Dairy cow welfare assessment on Algerian farms. AJAR. 2015; 10(9):895-901. DOI: $10.5897 / A J A R 2015.9483$.

8. Bernardi F, Fregonesi J, Winckler C, Veira DM, von Keyserlingk MA, Weary DM. The stall-design paradox: neck rails increase lameness but improve udder and stall hygiene. J Dairy Sci. 2009; 92(7):3074-3080. doi:10.3168/jds.2008-1166.

9. Bouraoui R, Selmi H, Mekni A, Chebbi I, Rouissi H. Impact of housing conditions and milking practices on mammary health and milk quality of dairy cows in Tunisia. Livest Rest Rural Dev. 2014; 26(3).

10. Bouraoui R, Selmi H, Mekni A, Chebbi I, Rouissi H. Impact of housing conditions and milking practices on mammary health and milk quality of dairy cows in Tunisia. Livest Rest Rural Dev. 2014; 26(3).

11. Brochart M, Fayet JC. Environment and foot pathology of dairy cows. In "Environment, pathology and prevention in ruminants" INRA Publ., France; 1981; p. 39-44.

12. Buckley F, Sullivan KO, Mee JF, Evans RD, Dillon P. Relationships among milk yield, body condition, cow weight, and reproduction in spring-calved Holstein-Friesians. J Dairy Sci. 2003; 86:2308-2319.

13. Bugueiro A, Fouz R, Diéguez FJ. Associations between on-farm welfare, milk production, and reproductive performance in dairy herds in Northwestern Spain. J Appl Anim Welf Sci. 2020; 24(1):29-38. DOI: 10.1080/10888705.2020.1750016.

14. Burow E, Thomsen PT, Rousing T, Sorensen JT. Daily grazing time as a risk factor for alterations at the hock joint integument in dairy cows. Animals. 2013; 7(1):160-166. doi:10.1017/S1751731112001395.

15. Chapinal N, De Passille' AM, Rushen J. Correlated changes in behavioral indicators of lameness in dairy cows following hoof trimming. J of Dairy Sci. 2010; 93:5758-5763.

16. Coignard M, Guatteo R, Veissier I, Lehébel A, Hoogveld C, Mounier L, Bareille N. Does milk production reflect the level of welfare in dairy herds? Vet J. 2014; 199:184-187.

17. Cook BN. Prevalence of lameness among dairy cattle in Wisconsin as a function of housing type and stall surface. J Am Vet Med Assoc. 2003; 223(9).

18. Cook NB, Nordlund KV. The influence of the environment on dairy cow behavior, claw health and herd lameness dynamics. Vet. J. 2009; 179:360-369.

19. Coulon JB, Dauver F, Garel JP. Factors of milk cell count variation in dairy cows free from clinical mastitis. INRA $\begin{array}{llll}\text { Prod Anim. } & \text { A(2):133-139. }\end{array}$ http://www6.inra.fr/productions-animales/1996-Volume-9/Numero-2-1996/Facteurs-de-variation-de-la-num eration-cellulaire-du-lait-chez-des-vaches-laitieres

20. Crump A, Jenkins K, Bethell EJ, Ferris CP, Arnott G. Pasture access affects behavioral indicators of wellbeing in dairy cows. Animals (Basel). 2019; 9(11). doi:10.3390/ani9110902.

21. Darej C, M'hamdi N, Attia K, Hamzaoui S, M'hamdi H, Mrabet K, Bouraoui R. Effects of livestock practices on animal wellbeing and milk quality in the Holstein cow in Tunisia. J New Sci. Agric Biotechnol. 2019; 65(2):4066-4076.

22. De Pinho Manzi M, Nobrega DB, Faccioli PY, Troncarelli MZ, Menozzi BD, Langoni H. Relationship between teatend condition, udder cleanliness and bovine subclinical mastitis. Res Vet Sci. 2012; 93(1):430-434. doi:10.1016/j.rvsc.2011.05.010.

23. De Vries M, Bokkers EAM, Dijkstra T, van Schaik G, De Boer IJM. Invited review: Associations between variables of routine herd data and dairy cattle welfare indicators. J Dairy Sci. 2011; 94:3213-3228.

24. Dohme-Meier F, Kaufmann LD, Görs S, Junghans P, Metges CC, Van Dorland HA, Bruckmaier RM, Münger A. Comparison of energy expenditure, eating pattern and physical activity of grazing and zero-grazing dairy cows at different time points during lactation. Livest Sci. 2014; 162:86-96. http://dx.doi.org/10.1016/j.livsci.2014.01.006

25. DSA (Direction des Services Agricole). Annual report of the agricultural services of the Wilaya of Constantine. 2018.

26. Faye B, Barnouin J. Objectification of the cleanliness of dairy cows and stalls: The cleanliness index. Technical Bulletin. Zootechnical and Veterinary Research Center of Theix. 1985; 59:61-67.

27. Faye B, Barnouin J. Lameness in dairy cows, Summary of the results of the continuous Eco-Pathological survey. INRA Prod Anim. 1988; 1(4):227-234. https://doi.org/10.20870/productions-animales.1988.1.4.4456

28. Faye B, Fayet JC. Continuous Eco-Pathological Survey: 11. Evolution of pathological frequencies in dairy cattle farming according to the stage of lactation. Ann Rech Vét. 1986; 17(3):247-255.

29. Ferguson JD, Galligan DT, Thomsen N. Principal descriptors of body condition in Holstein dairy cattle. J Dairy Sci. 1994; 77:2695-2703. doi: 10.3168/jds.S0022-0302(94)77212-X.

30. Fraser D. The globalisation of farm animal welfare. Rev Sci Tech. 2014; 33(1):33-38.

31. Fulwider WK, Grandin T, Garrick DJ, Engle TE, Lamm WD, Dalsted NL, Rollin BE. Influence of free-stall base on tarsal joint lesions and hygiene in dairy cows. J Dairy Sci. 2007; 90(7):3559-3566. doi:10.3168/jds.2006-793.

32. Gergovska Z, Miteva T, Angelova T, Yordanova D, Mitev J. Relation of milking temperament and milk yield in Holstein and Brown Swiss cows. Bulgarian J Agric Sci Technol. 2012; 17:837-845. 
33. Gibbons J, Vasseur Rushen EJ, De Passillé A. A training programme to ensure high repeatability of injury scoring of dairy cows. Anim Welf. 2012; 21(3):379-388.

34. Guyot H, Théron L, Frisée V, Hanzen C, Rollin F. Herd medicine clinic notebook. Ed. University of Liège. Faculty of Veterinary Medicine. Clinical Department of Production Animals. 2014.

35. Haskell MJ, Rennie LJ, Bowell VA, Bell MJ, Lawrence AB. Housing system, milk production, and zero-grazing effects on lameness and leg injury in dairy cows. J Dairy Sci. 2006; 89:4249-4266.

36. Hernandez-Mendo 0, von Keyserlingk MAG, Veria DM, Weary DM. Effects of pasture on lameness in dairy cows. J Dairy Sci. 2007; 90:1209-1214. https://doi.org/10.3168/jds.S0022-0302(07)71608

37. Hristov S, Relić R. Assessment of housing conditions with reference to the welfare of cows. Proceedings of the Institute of PKB Agroeconomics. 2009; 15(3):79-88.

38. Huxley JN. Impact of lameness and claw lesions in cows on health and production. Livest Sci. 2013; 156(1-3):6470.

39. Kathambi EK, VanLeeuwen JA, Gitau GK, Kamunde C. Risk factors associated with cows lying time, stall and cows own cleanliness in smallholder dairy farms in Kenya. Vet World. 2019; 12:1085-92.

40. Keil NM, Wiederkehr TU, Friedli K, Wechsler B. Effects of frequency and duration of outdoor exercise on the prevalence of hock lesions in tied Swiss dairy cows. Prev Vet Med. 2006; 74:142-153.

41. Levesque P. How do the building and the equipment influence the quality of the milk? Institute of Agro-Food Technology. Department of management and operation of the agricultural enterprise. Dairy Cattle Symposium, France; 2004, 21 October.

42. Lombard JE, Tucker CB, Von Keyserlingk MA, Kopral CA, Weary DM. Associations between cow hygiene, hock injuries, and free stall usage on US dairy farms. J Dairy Sci. 2010; 93(10):4668-4676. doi:10.3168/jds.2010-3225.

43. M'hamdi N, Darej C, Ben Larbi M, Frouja S, Kaur Brar S, Ben Hamouda M. Multi-criteria assessment of the wellbeing and adaptation of the Holstein cow in some dairy farms in Tunisia. Nature \& Technologie B-Sciences Agronomiques et Biologiques. 2014; 10:45-49.

44. M'Sadak Y, Hamed I, Hamdi H, Kraiem K. Assessment of breast health conditions and induced milk losses in aboveground cattle farming in the dairy cradle of Mahdia (Tunisia). Nature \& Technologie B-Sciences Agronomiques et Biologiques. 2015; 12:27-36.

45. MADR (Ministère de l'Agriculture et du Développement Rural) (2018). Presentation report on the agricultural campaign. 2010/2017, 3 p.

46. Molomo M, Mumba T. Drivers for animal welfare policies in Africa. Rev Sci Tech. 2014; 33(1):47-53.

47. Mtaallah B, Oubey Z, Hammami H. Estimation of milk production losses and risk factors for subclinical mastitis from tank milk cell counts in dairy cattle farming. Rev Med Vet. 2002; 153(4):251260. http://www.revmedvet.com/2002/RMV153 251_260.pdf

48. Norring M, Manninen E, De Passillé AM, Rushen J, Munksgaard L, Saloniemi H. Effects of sand and straw bedding on the lying behaviour, cleanliness, and hoof and hock injuries of dairy cows. J Dairy Sci. 2008; 91:570-576.

49. Olmos G, Boyle L, Hanlon A, Patton J, Murphy JJ, Mee JF. Hoof disorders, locomotion ability and lying times of cubicle-housed compared to pasture-based dairy cows. Livest Sci. 2009; 125:199-207.

50. Ostojić-Andrić D, Hristov S, Petrović MM, Pantelić V, Bojkovski J, Nikšić D, Mićić N. Dairy cows' welfare quality in different seasons. International Symposium on Animal Science; Herceg Novi, Montenegro. 2017 June 5-10.

51. Popescu S, Borda C, Diugan EA, El Mahdy C, Spinu M, Sandru CD. Qualitative behaviour assessment of dairy cows housed in tie- and free stall housing systems. Bull Univ Agric Sci Vet Med. Vet. Med. 2014a; 71(1):276-277.

52. Popescu S, Borda C, Diugan EA, Niculae M, Stefan R, Sandru CD. The Effect of the housing system on the welfare quality of dairy cows. Italian J Anim Sci Biotechnol. 2014b; 13:2940.

53. Popescu S, Borda C, Diugan EA, Spinu M, Groza IS, Sandru CD. Dairy cows welfare quality in tie-stall housing system with or without access to exercise. Acta Vet Scand. 2013; 55:43.

54. Potterton SL, Green MJ, Harris J, Millar KM, Whay HR, Huxley JN. Risk factors associated with hair loss, ulceration and swelling at the hock in free stall-housed UK dairy herds. J Dairy Sci. 2011; 94:2952-2963.

55. Raboisson D, Mounié M, Maigné E. Diseases, reproductive performance, and changes in milk production associated with subclinical ketosis in dairy cows: A meta-analysis and review. J Dairy Sci. 2014; 97:7547-7563.

56. Relić R, Vuković D. Reproductive problems and welfare of dairy cows. Bull Univ Agric Sci Vet Med. Vet. Med. 2013; $70(2)$.

57. Rousing T, Bonde M, Sørensen JT. Indicators for the assessment of animal welfare in a dairy cattle herd with cubicle housing system. In: Blokhuis HJ, Ekkel ED, Wechsler B, editors. Improving health and welfare in animal production. EEAP Publ. N. 102. Academic Press Ltd., London, UK; 2000. p. 37-44.

58. Rutherford KMD, Langford FM, Jack MC, Sherwood L, Lawrence AB. Haskell M.J. Hock injury prevalence and associated risk factors on organic and nonorganic dairy farms in the United Kingdom. J Dairy Sci. 2008; 91:22652274.

59. Schreiner DA, Ruegg PL. Relationship between udder and leg hygiene scores and subclinical mastitis. J Dairy Sci. 2003; 86: 3460-3465. 
60. Shepley E, Lensink J, Leruste H, Vasseur E. The effect of free-stall versus strawyard housing and access to pasture on dairy cow locomotor activity and time budget. Appl Anim Behav Sci. 2019a. doi: https://doi.org/10.1016/j.applanim.2019.104928

61. Shepley E, Obinu G, Bruneau T, Vasseur E. The effect of housing tie-stall dairy cows in deep- bedded pens during an eight-week dry period on lying time, lying postures, and rising and lying-down behaviors. J Dairy Sci. 2019b; 102(7): 6508-6517. https://doi.org/10.3168/jds.2018-15859

62. Sillett N, Moore A, Haupstein D, Tremblay P, Robinson S, Taylor T, Skerritt M, Lévesque P, Anderson D, Esau C, Sampson R. Canadian quality milk. Reference manual. Dairy farmers of Canada. 2003; 164 p.

63. Sogstad AM, Fjeldaas T, Osteras O. Lameness and claw lesions of the Norwegian Red Dairy Cattle housed in loose stalls in relation to environment, parity and stage of lactation. Acta Vet Scand. 2005; 46:203-217.

64. Sprecher DJ, Hostetler DE, Kaneene JB. A lameness scoring system that uses posture and gait to predict dairy cattle reproductive performance. Theriogenology. 1997; 47(6):1179-1187. doi: 10.1016/s0093-691x(97)00098-8.

65. Studer E. A veterinary perspective of on farm evaluation of nutrition and reproduction. J Dairy Sci. 1998; 81:872876.

66. Sundrum A. Metabolic disorders in the transition period indicate that the dairy cows' ability to adapt is overstressed. Animals. 2015; 5:978-1020.

67. Tsuruta S, Miszatal I, Lawlor TJ. Genetic correlations among production, body size, udder, and productive life traits over time in Holsteins. J Dairy Sci. 2004; 69:510-517.

68. Vokey FJ, Guard CL, Erb HN, Galton DM. Effects of alley and stall surfaces on indices of claw and leg health in dairy cattle housed in free-stall barn. J Dairy Sci. 2001; 84:2686-2699.

69. Vučemilo M, Matković K, Štoković I, Kovačević S, Benić M. Welfare assessment of dairy cows housed in a tie-stall system. Mljekarstvo. 2012; 62(1):62-67.

70. Wemelsfelder F, Mullan S. Applying ethological and health indicators to practical animal welfare assessment. Rev Sci Tech. 2014; 33(1):111-120.

71. Whay HR, Main DCJ, Green LE, Webster AFJ. Assessment of the welfare of dairy cattle using animal-based measurements: direct observations and investigation of farm records. Vet Rec. 2003; 153:197-202. http://dx.doi.org/10.1136/vr.153.7.197. 